\title{
STRUCTURAL ARCHITECTURE OF TARBOUL BASIN, SOUTHERN GULF OF SUEZ, EGYPT
}

\author{
Eslam Shaheen $^{a}$, Shawky Sakran ${ }^{b}$, Selim Saber ${ }^{b}$ \\ a Aminex Petroleum Egypt Limited, Cairo 11371, Egypt. \\ ${ }^{\mathrm{b}}$ Department of Geology, Faculty of Science, Cairo University, Cairo, 11566, Egypt
}

\begin{abstract}
The surface structural architecture basin configuration and petroleum system are important steps in studying and evaluating frontier sedimentary basins. The Tarboul basin $(\mathrm{TH})$ is a typical marginal half garben at the onshore part of the southern Gulf of Suez rift. It is bounded from the west by the NW-SE striking Oligo-Miocene rift boundary fault (RBF) and from the East by the NW-SE striking Gemsa basin major bounding fault. The TH has a tripartite geometry bordered by the RBF, rift onset unconformity and the post rift unconformity. The Pre-rift strata include undifferentiated Nubia sandstones of Paleozoic-Lower Cretaceous age, Raha Formation of Cenomanian age, Wata Formation of Turonian age, Matulla Formation of Coniacian Santonian age, Duwi Formation of Campanian age, Sudr Formation of Masstrachtian age and Thebes Formation of lower Eocene age. The synrift strata are represented by Lower Miocene Nukhul Formation and LowerMiddle Miocene Rudeis Formation. The Syn-rift packages roll into and stratigraphically thicken toward the RBF. The up dip northeastern part of the TH is characterized by a flexural faulted margin where there is an exposed monoclinal structure. Integrating surface and subsurface mapping of the monocline facilitated the prediction of the upward propagated fault that formed this structure. The TH has a SE plunging NW-SE oriented synclinal structure representing a hanging wall syncline related to the upward propagation of the RBF. The exposed Pre-Miocene rock units at the northwest part of this structure indicate the decrease in the throw of the RBF toward the onshore part of the adjoining Morgan Transfer Zone.
\end{abstract}

\section{Introduction}

Basement fault blocks often correlate with structural and stratigraphic features in the sedimentary section that control trap location. Magnetic technology senses the earth's magnetic field. This technology - and aeromagnetic, in particular-effectively delineates basement fault blocks through the use and interpretation of depth to basement map. Basement lithologic changes and the 
resulting magnetic susceptibility changes from block to block allow to map the basement fault block pattern and to use this information in important new ways for finding oil and gas. The main objectives of this paper is interpret the aeromagnetic map of the Tarboul basin in order to delineate it's the structural configuration of the underlying basement fault block pattern. The Aeromagnetic map in combination with the surface structural architecture are being used in this paper to delineate and unravel the major structural elements and the major structural.

\section{Methodology}

A preliminary basin structural architecture and configuration has been produced for the Tarboul basin by using a detailed interpretation of satellite maps, detailed field work, two seismic sections and aeromagnetic map all over the Tarboul basin, which are then integrated together to produce a robust basin structural configuration for this basin.

\section{Stratigraphy}

Many workers have discussed the stratigraphy of the Gulf of Suez. According to Said (1962 and 1990) and Darwish and El Azabi (1993), the stratigraphic succession of the Gulf of Suez rift is generally characterized by three main tectono-stratigraphic sequences relative to the Miocene rifting events, as prerift sequence (including the Precambrian basement rocks and a sedimentary succession up to the Oligocene), Synrift sequence (Early-Middle Miocene successions), and Post rift sequence (Late Miocene to Recent successions). The first and second sequences include important hydrocarbon Source and reservoir rocks while the third depositional sequence is important because of its evaporitic seal (Fig.1). The major sedimentary successions accumulated under different structural settings on the Precambrian Basement Complex with distinct inter-and intraformational unconformities and hiatuses of different magnitudes.

The stratigraphic setting of the Tarboul Basin is summarized in a composite section (Fig.2) compiled from measured surface sections and WEEM-1 well, which is the only drilled well in the Tarboul basin. The Precambrian crystalline basement rocks are the oldest rocks in the (Tarboul) Basin, where these rocks are covered by sedimentary succession of PreRift, Syn-rift and post-rift sequences. The pre-rift sequence comprises; Early Paleozoic to Early Cretaceous fluviatile to shallow marine sandstones (Undiff Nubia-Malha formations). It ranges in thickness from $92 \mathrm{~m}$ to $300 \mathrm{~m}$.Late Cretaceous Clastic group ranges from Cenomanian to Santonian age that developed during the transgression of the Tethys Ocean. (Raha, Wata and Matulla Formations). 


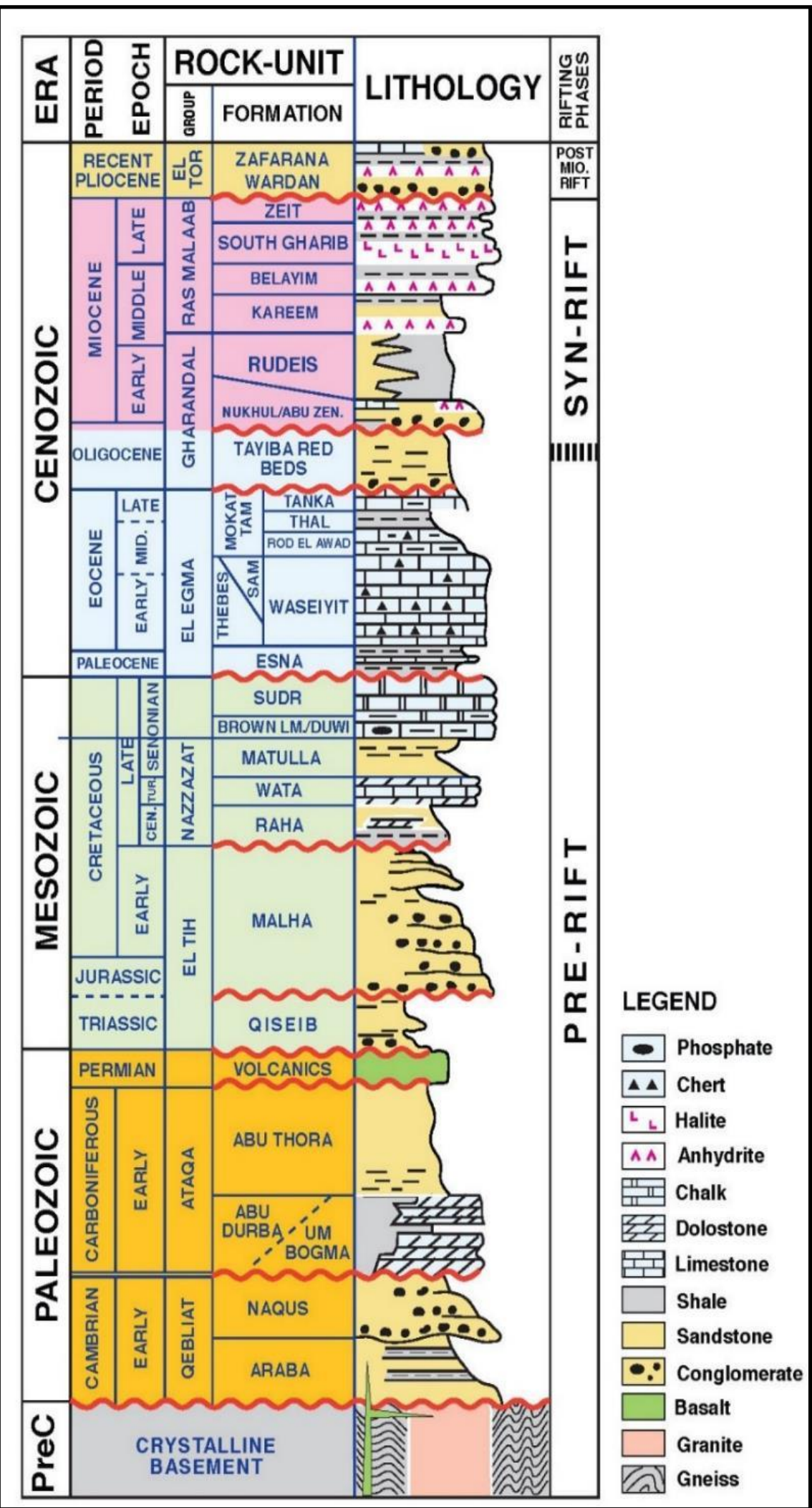

Fig.1: General stratigraphy of the eastern Gulf of Suez (modified from Darwish, pers. comm. 1993). 
The Raha attains a maximum thickness of $27 \mathrm{~m}$, while Wata Formation attains a thickness of $13 \mathrm{~m}$. and The Coniacian-Santonian Matulla Formation thickness ranges from $70 \mathrm{~m}-190 \mathrm{~m}$. The Late Cretaceous Carbonate Group which is represented mainly by the Campanian Duwi brown limestone thickness ranges from 6-17 m. The Masstrachtian Sudr Chalk thickness ranges from 34-75 $\mathrm{m}$. The Paleocene rock, which is represented by Esna Formation, is made up of very small streak of shale, which has a thickness of about $9 \mathrm{~m}$. The Eocene Rocks, which is represented by Thebes Formation is made up of mainly limestone with numerous chert bands and ranges in thickness from $68 \mathrm{~m}$ to $108 \mathrm{~m}$.

The Syn rift rocks are made up mainly of the Oligocene basaltic lava, and Miocene sediments. The Miocene sediments are represented mainly by Abu Gerfan formation (Nukhul Equivalent), which attains a thickness of about 25 $\mathrm{m}$, Gharamul formation (Rudeis, Abu Alaqa formations equivalent) that attains a thickness of about $121 \mathrm{~m}$. The post-rift sediments consist of blanket of coarse and fine clastics of El Tor Formation of Plio-Pleistocene age.

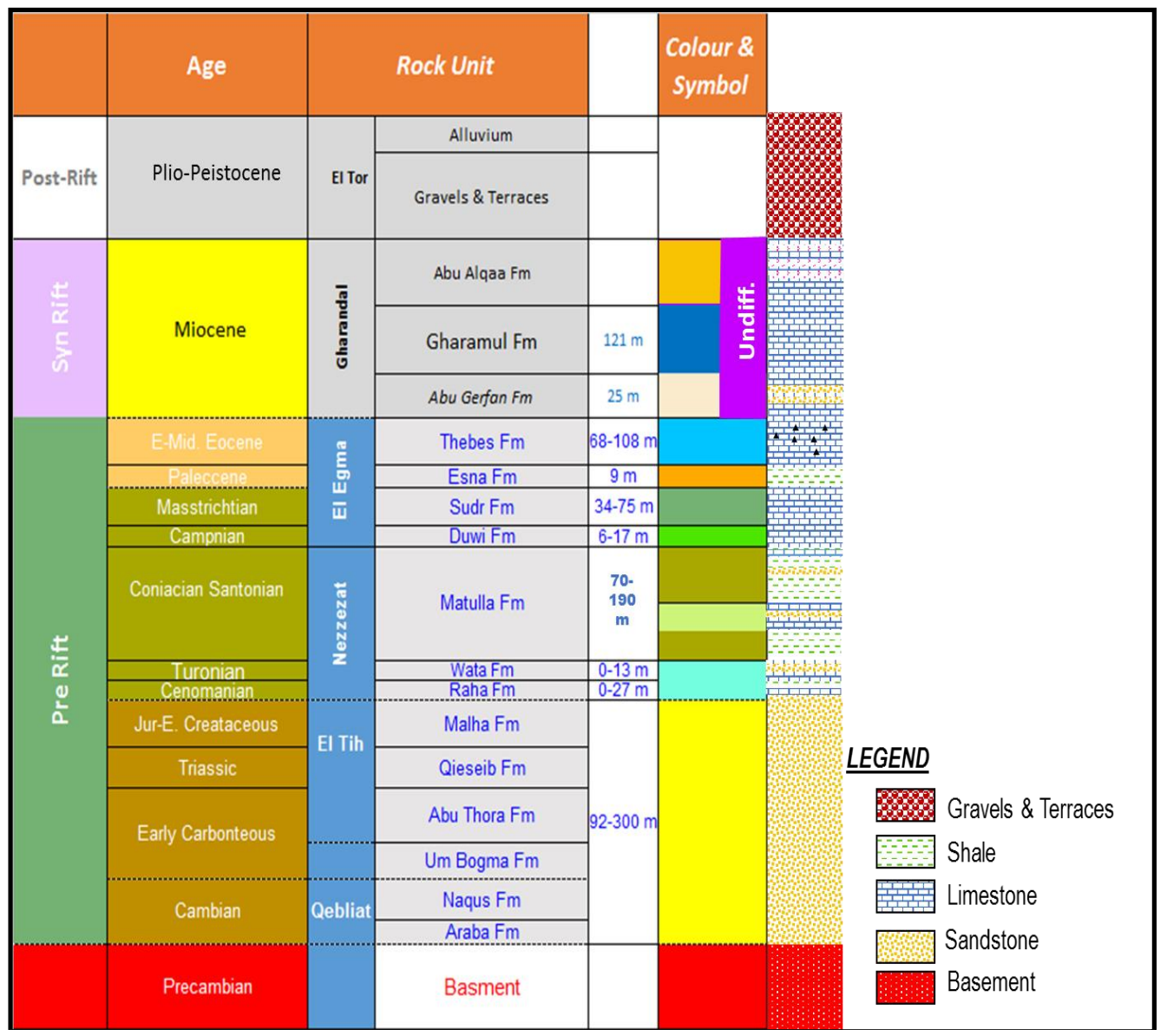

Fig.2: Simplified Stratigraphic log of Tarboul Basin (Modified after Aboul karamat, 1987). 


\section{Regional structural setting}

The Gulf of Suez rift is a northwest trending arm of the Cenozoic red sea rift system that formed in response to late Oligo-Miocene rifting of the African and Arabian plates (Garfunkel 1988, colleta et al 1988 and Patton 1994). The rift is $300 \mathrm{~km}$ long, up to $80 \mathrm{~km}$ wide. At its northern end, the Suez dies out beneath the Nile delta, and in the south, it terminates against the NE Trending Gulf of Aqaba-Dead Sea transform fault. The rift margins are delineated by large throw (2 to $5 \mathrm{~km}$ [1 to $3 \mathrm{mi}]$ ) normal fault systems, and the rift itself is characterized by a broadly northwest-trending, ca. $20 \mathrm{~km}$ (12 mi) wide, normal fault-bound garben and half-garben (Patton et al1994). The rift contains three dip provinces (Northern, Central, and southern), which are separated by broad NE trending Accommodation zones (Colleta et al 1988, Patton et al 1994).

The Suez rift is dominated by NNW-SSE to NW-SE oriented faults bounding tilted fault blocks. Pre-rift and Syn-rift rocks dip at an average angle of about $10^{\circ}-15^{\circ}$ but locally increase to as much as $45^{\circ}$ in the southern part of the rift because of increase in extension from northwest to southeast (Colletta et al., 1988; Patton et al., 1994). The Suez rift includes a number of rift blocks that extends several tens of kilometers in length and width and includes a group of smaller tilted fault blocks.

\section{Surface structures of the Tarboul basin}

The Tarboul basin is located on the western margin of the Suez rift and lies within the southern dip province (Fig.3). it is a $63-\mathrm{km}$ long by $25-\mathrm{km}$ wide marginal rift half garden and is bound to the west by the Precambrian igneous and metamorphic rocks of the Red Sea Hills. The Tarboul basin is separated from the Red Sea Hills by the Red sea Hills boundary fault (RBF). This fault striking Northwest - southeast and dips in NE direction with average throw up to $(10 \mathrm{~km})$. To the east, the basin is bounded by Esh El Mellaha range striking northwest - southeast which is considered to be the longest range in Suez rift separating two different basins; the eastern Gemsa basin and the western Tarboul basin. Based on Detailed field observation integrated with satellite images (Scales 1:50,000 and 1: 100,000) and previous work studies, a detailed surface geological map has been generated.

The Tarboul Basin (Fig.4) consists mainly of Five main NW-SE trending sedimentary cuestas including from north to south: Gebel tarboul, Gebel Sufr el Dip, Gebel Sufr Abu Had, Gebel Sufr El Mellaha and Gebel Sufr el Esh. These cuestas are made up from sedimentary rocks range in age from Paleozoic ton Eocene age.

The Study area is dissected by three major faults (Fig.5) the main rift boundary fault to the west, the Gemsa fault to the northeast and the Abu Shaar 
fault the southeast. The main Rift boundary fault is striking NW-SE and dipping in the NE direction. The Gemsa fault is striking NW-SE and dipping in the NE direction and Juxtaposes the Esh El Mellaha basement Range in the up thrown against the quaternary sediments in the downthrown. The Abu Shaar fault is striking NE-SW and dipping in the SE direction, this fault juxtaposes the Gharamul Formation against the quaternary deposits.

The western side (Fig.6) of the Central block is characterized by the occurrence of NW Clysmic faults (RF-1, RF'-1, RF-2 and RF'-2) which are dissected by Wad El Mellaha NE oriented fault (WEM X-1). The WEM X-1 fault is an ENE oriented fault, which dips in the NNW direction with an average dip of about $65^{\circ}$. This fault juxtaposes the Nubian S.st against the Eocene rocks.

In the up thrown of the WEM X-1 fault, the Nubian sandstone has a very gentle dip of about $3^{\circ}$ towards the SE Direction. The Abu Marwa inner block lies between the Rift boundary fault and the basin bounding fault and is bounded from the eastern side by the major basin-bounding fault RF-2 that strikes almost NW-SE and dips in the SE direction. This fault juxtaposes the Abu Marwa Inner Block Nubian sandstone overlying the Precambrian Basement against the Quaternary deposits. Generally, the Abu Marwa Inner Block-1 shows a plunging towards the $\mathrm{N}$ direction. The Eocene rocks exposed to the west of the inner block dip in the NE direction, which is interpreted as a drag syncline, occurred at the rift boundary fault (Fig.7). This Eocene rocks lies also in the downthrown of the NW-SE striking RF'-2 fault which juxtapose the Nubian sandstones with underlying basement rocks against the Eocene rocks in the downthrown.

In the downthrown of the WEM X-1 fault, there is Abu Marwa Inner Block 2, the WEEM-1 well was drilled (Fig.8). This block is bounded from the west by the Eocene rocks which have a moderate dip $20^{\circ}-25^{\circ}$ towards the NE direction which is capped by the lower Miocene rocks which dips in the same direction. The eastern side of the Abu Marwa Inner block -2 is bounded by the Major Basin Bounding Fault RF-1 which strikes almost NW-SE and dips in the SE Direction. Generally, Abu Marwa horst Inner Blocks 1 and 2 are in the footwall of RF-2 and RF-1 respectively, which represents an uplifted rift flank with almost a complete erosion of the synrift sediments. The NW trending ridge of Gebel Sufr El Mellaha (Fig.6), is bounded from east by the NW-SE GEMSA basin bounding fault which juxtaposes the ESH El Mellaha Precambrian rocks against the Quaternary deposits.

The NW-SE trending range of the granitic Precambrian rocks of Esh El Mellaha range is overlain by the lower part of the Nubia sandstone which have a gentle dip $\left(7^{\circ}-9^{\circ}\right)$ (Fig.9A) towards the SW direction. The ConiacianSantonian age Matulla Formation overlay the Nubian s.st. The Matulla 
formation has a moderate dip $\left(11^{\circ}-14^{\circ}\right.$ (Fig.9B) towards the SW direction. The Matulla formation is dissected by E-W normal faults that form a very remarkable drag patterns due to highly shale content. The Matulla Formation is overlain by the carbonate rocks of Campanian - Masstrachtian age Sudr and Duwi Formations which have a very steep dip range between $44^{\circ}-69^{\circ}$ (Fig.9C) in the SW direction. The Eocene limestone rocks have a moderate dip of about $21^{\circ}$ (Fig.9D) in the SW direction.

The very remarkable change in dip is well illustrated in dip Vs. Azimuth Plot (Fig.10). There are two main dip domains which are observed in this plot, the drag pattern domain which have a dip from $44^{\circ}$ to $70^{\circ}$ in the SW direction and the regional block dip which have dip ranges from $9^{\circ}-14^{\circ}$ in the same direction. The $\mathrm{T}$ plane direction for this curvature having an azimuth about $240^{\circ}$, where the L plane direction have an azimuth about $330^{\circ}$. This curvature is interpreted as a longitudinal monocline, and the $\mathrm{L}$ plane direction represents the strike of fault along which the monocline has been formed. This monocline is being breached as represented by the MF-1 fault which has $74^{\circ}$ dip towards the SW direction and MF-2 fault which has $68^{\circ}$ dip towards the NE direction.

Surface structural cross section has been generated (Fig.11) using the elevation, stratigraphic contacts and structural dip of the formation. The (DD') structural cross section shows that the monocline is being breached by the MF-2 NW-SE striking normal fault. There is also a gradually thinning towards the fault due to the drag effect. the Gemsa Fault is a NW-SE Striking normal fault bounding the Esh El Mellaha basement range in the up thrown.

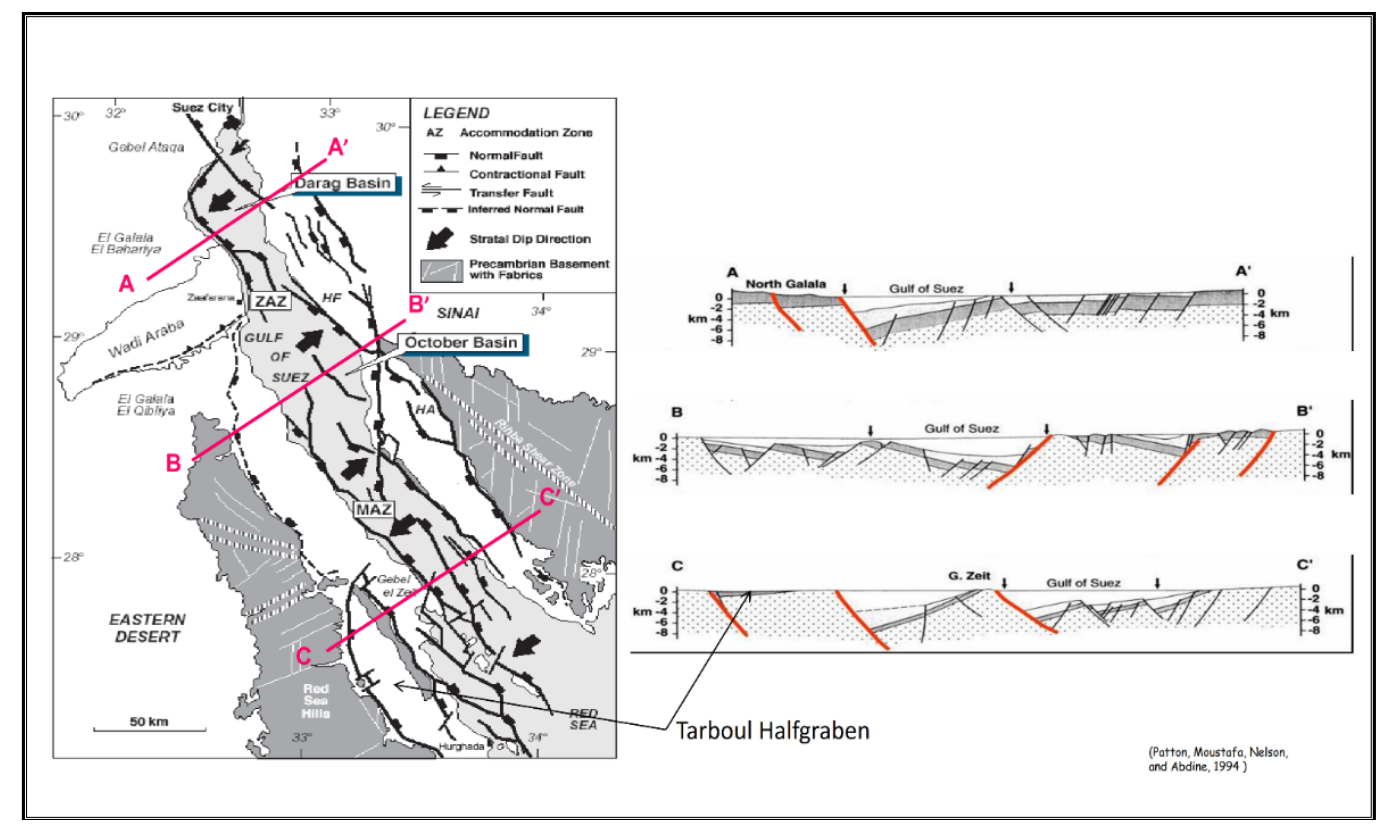

Fig.3: Location Map of the Tarboul basin (Modified after Patton et al 1994). 


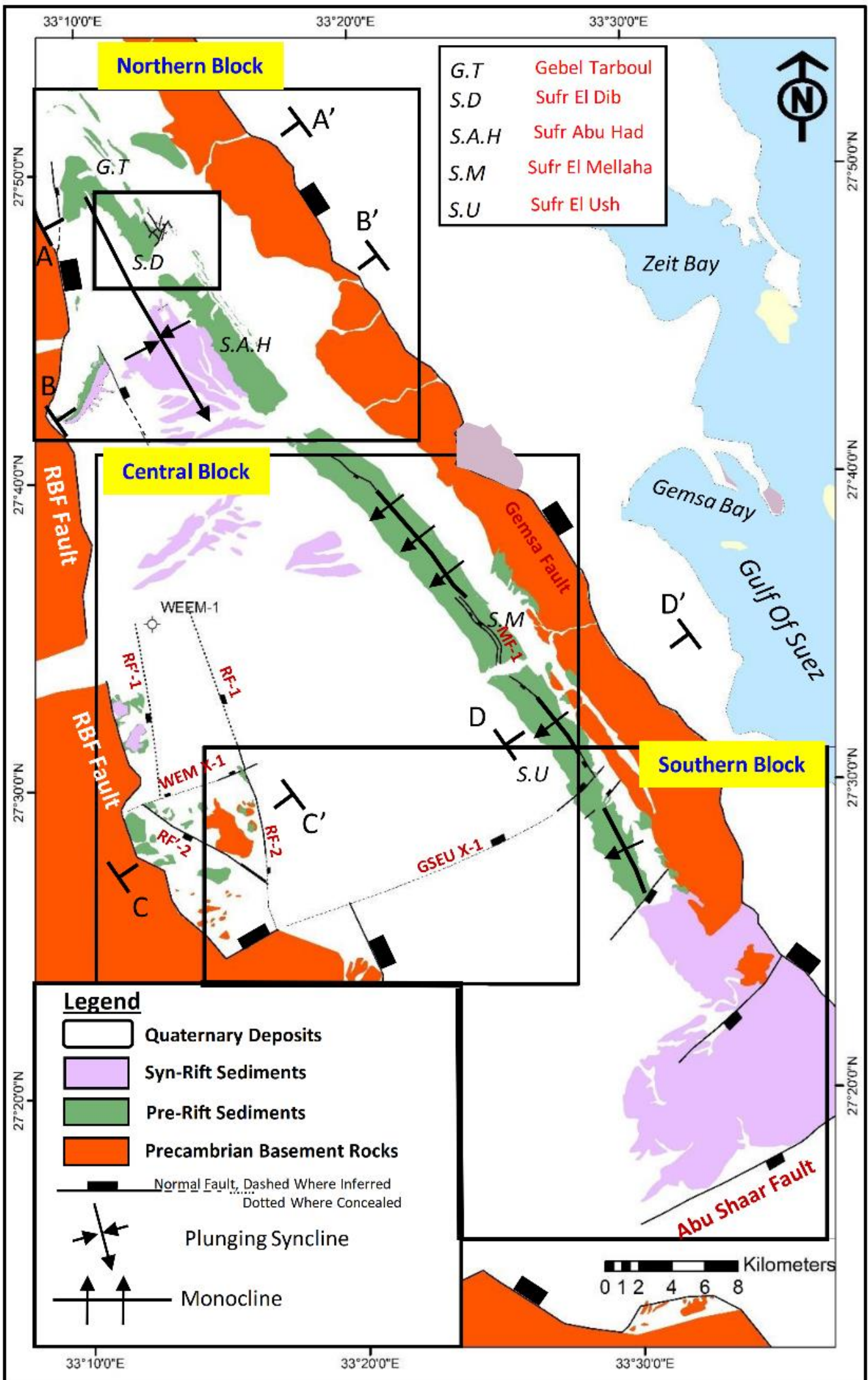

Fig.4: Simplified geological map of Tarboul Basin. 


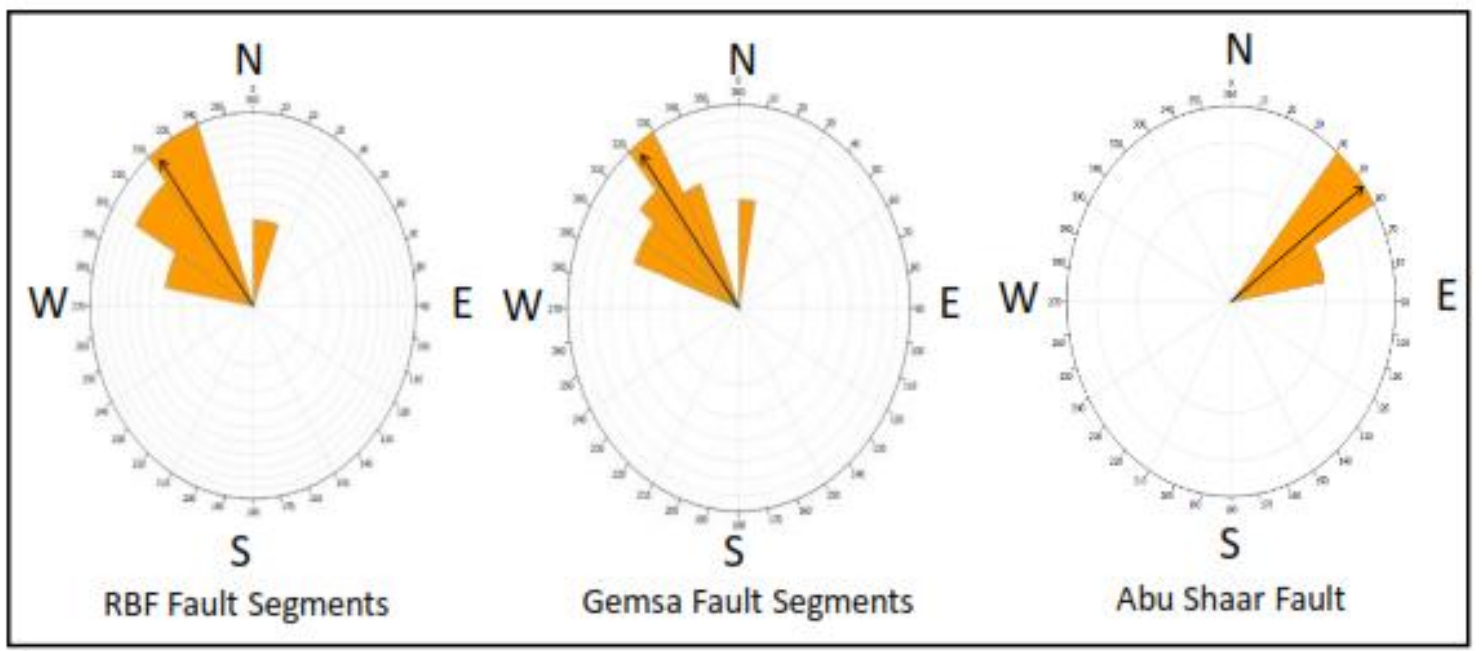

Fig.5: Rose diagram of the major faults trends affecting the study area.

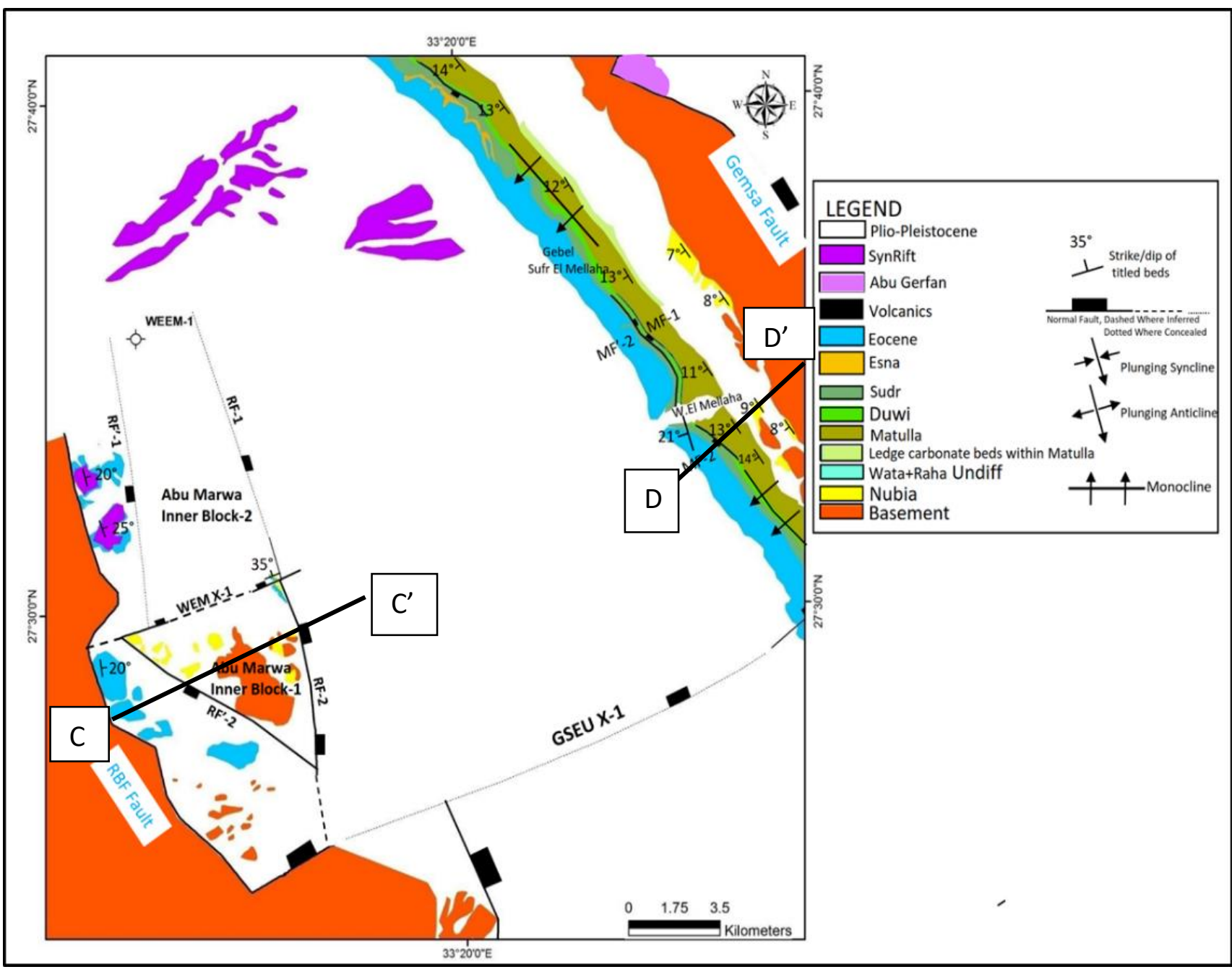

Fig.6: Surface Geological map of Block. 


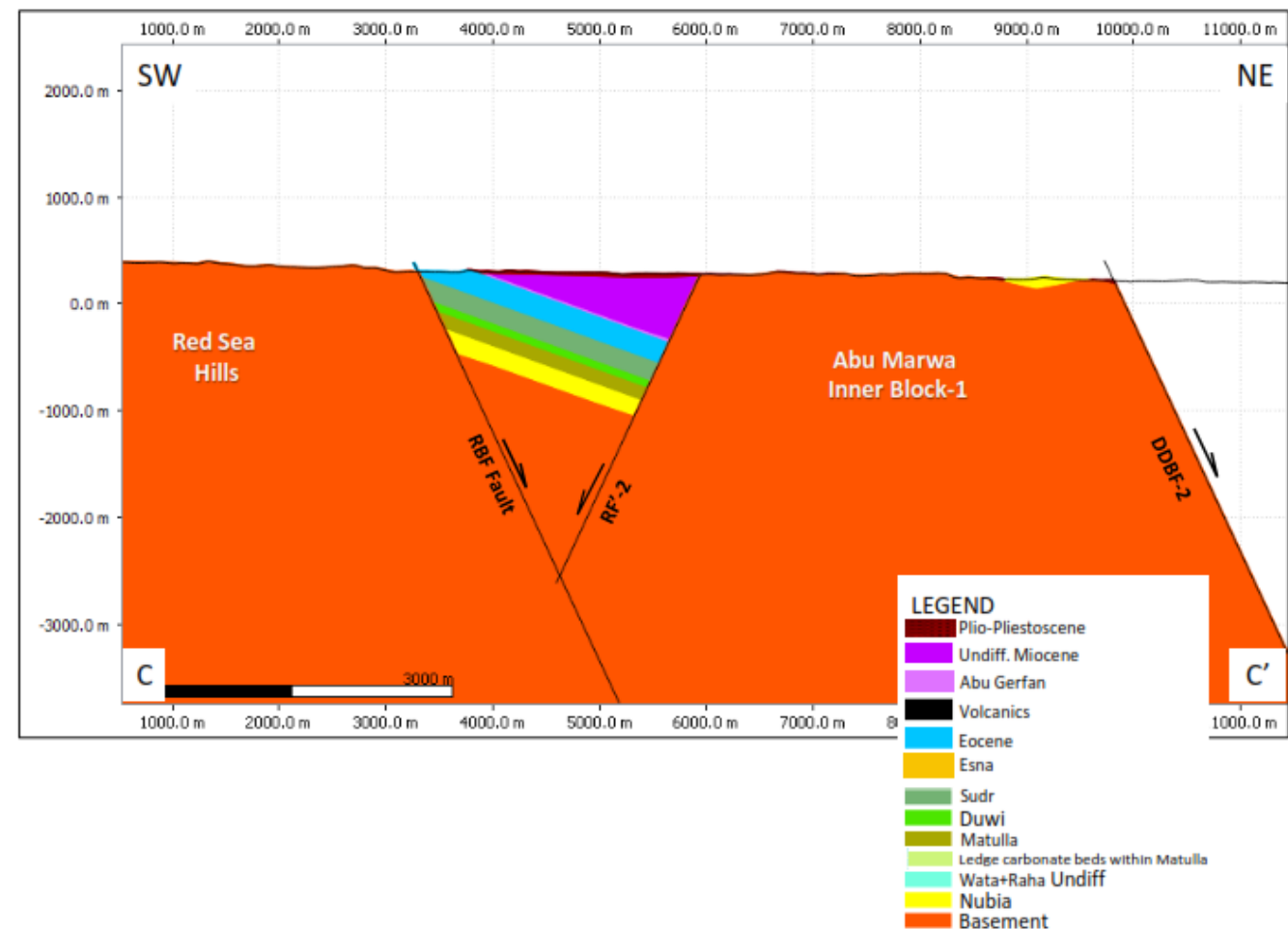

Fig.7: Structural X Section along C-C'.

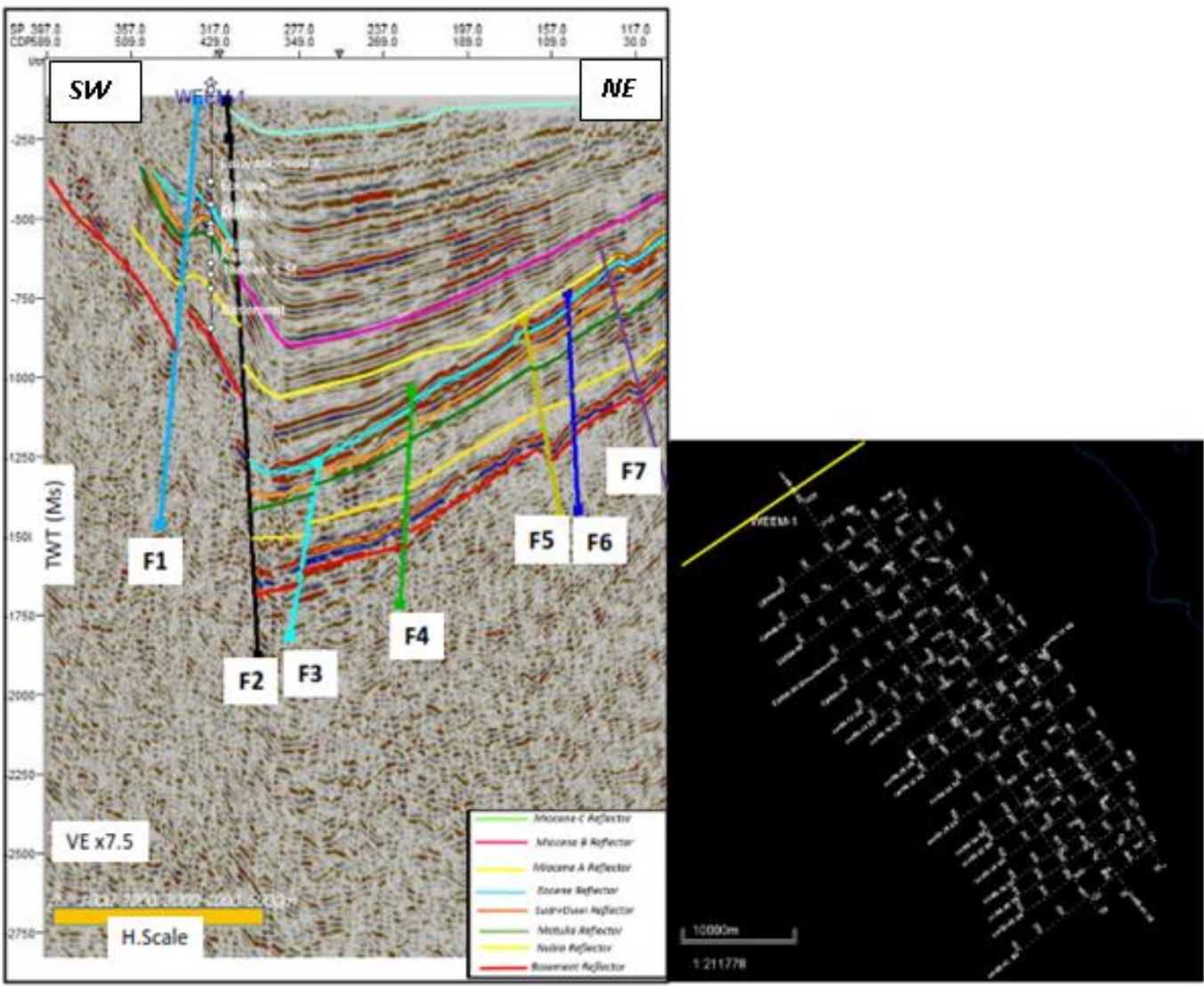

Fig.8: NE-SW dip Seismic line. 


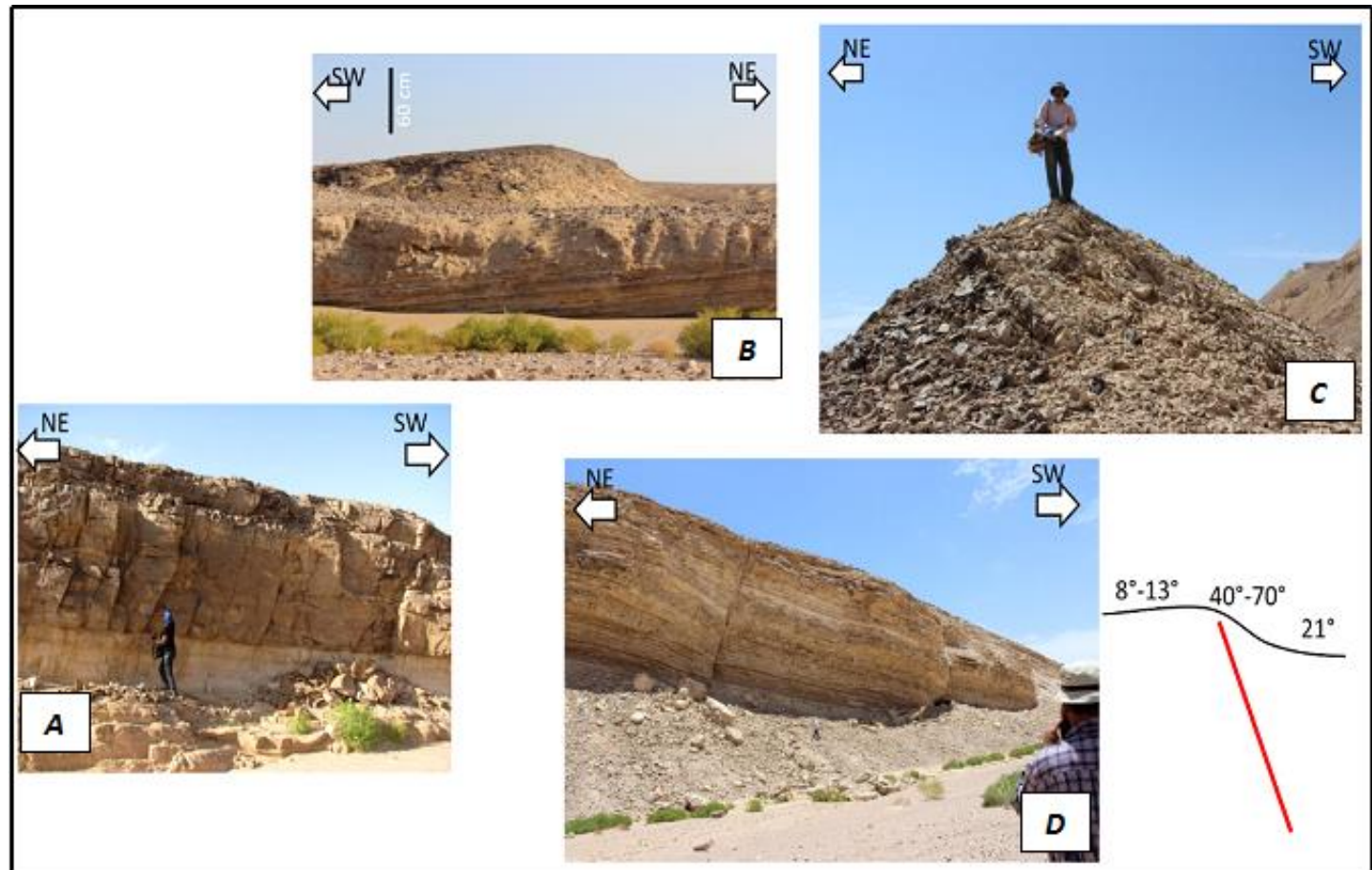

Fig.9: A: Gentle dip of the Nubian S.ST. B: Gentle Dip of the Matulla Formation. C: Steep dip of the Duwi Formation. D: Moderate dip of the Eocene Formation.

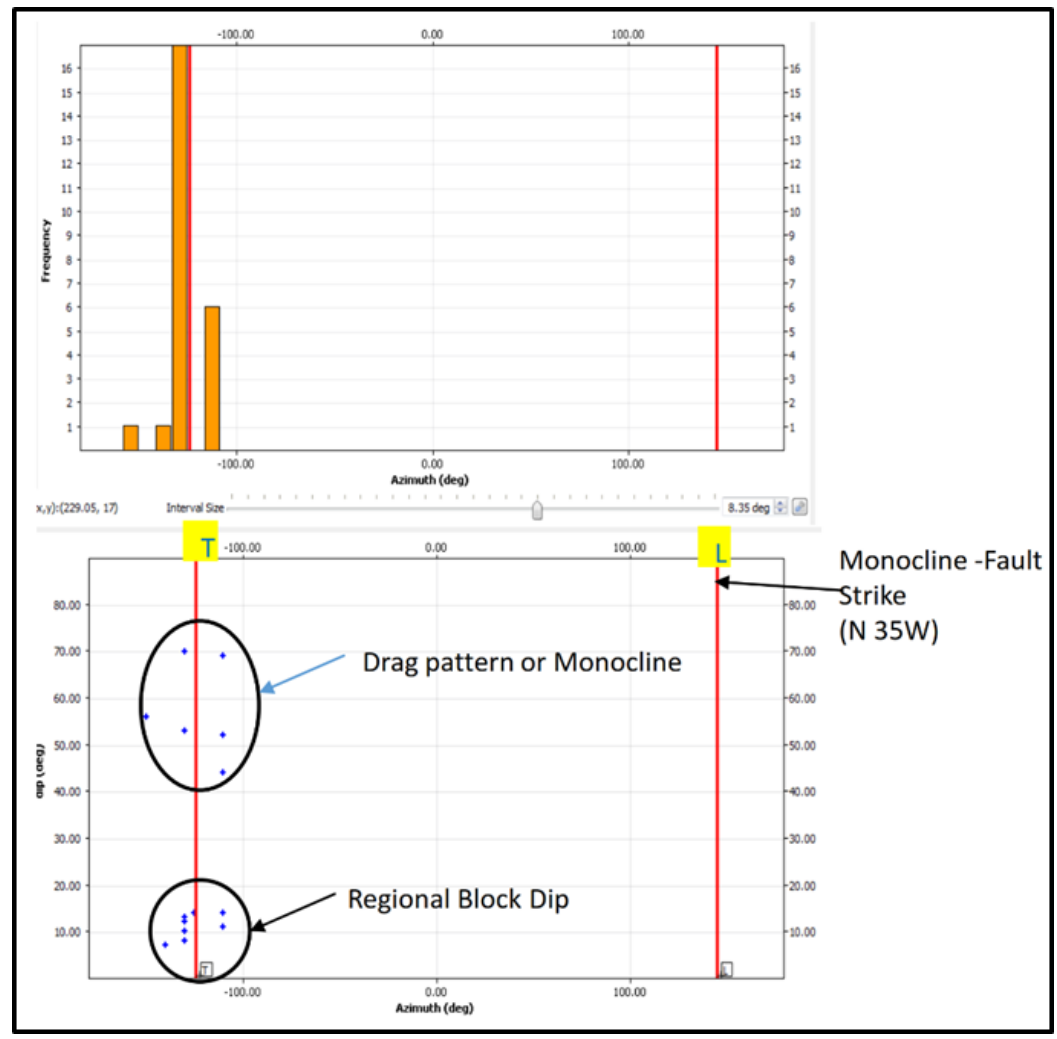

Fig.10: Statistical curvature analysis of Monocline at the Esh El Mellaha Monoclinal Range. 


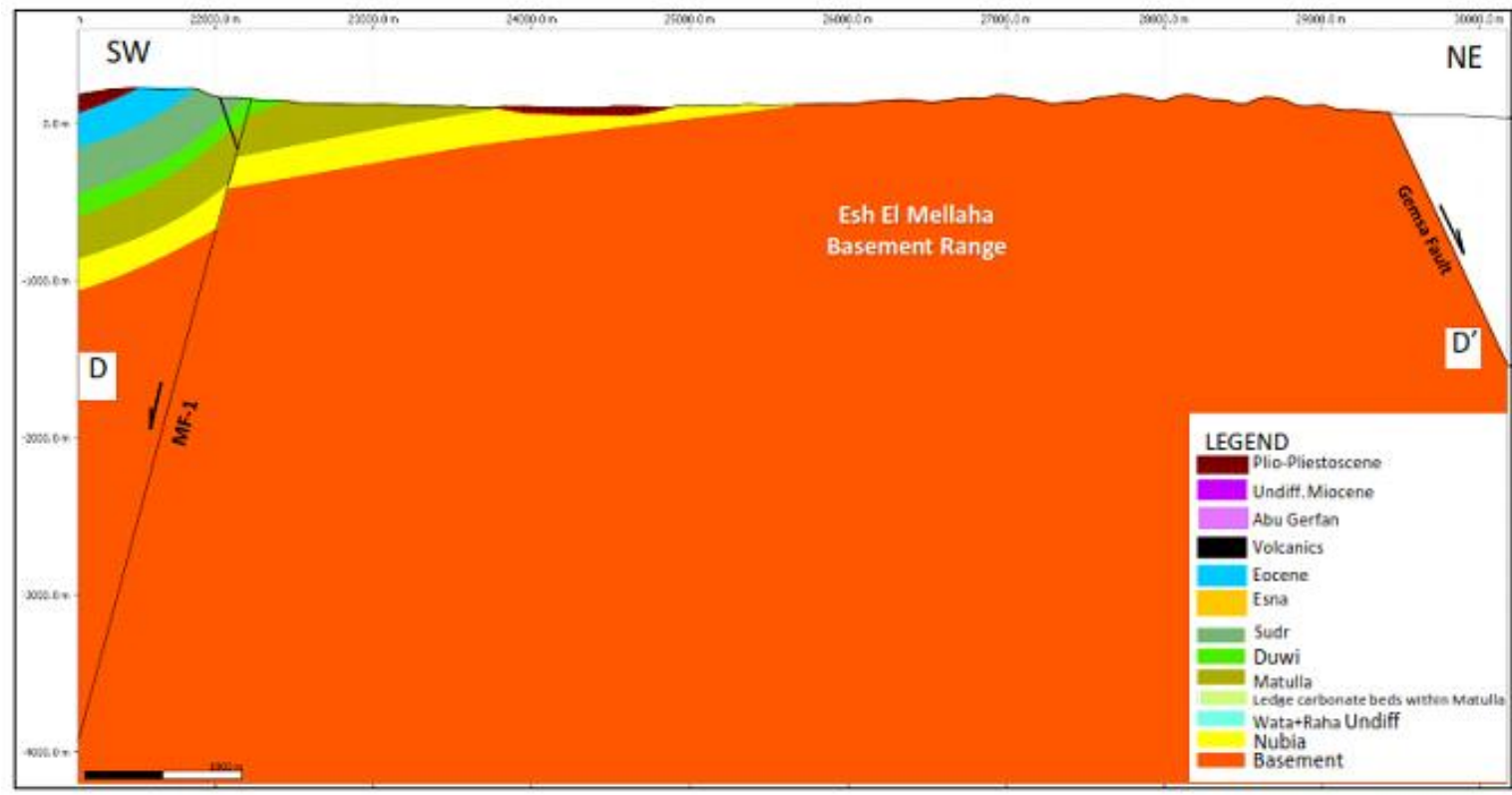

\section{Southern Block}

Fig.11: Structural X Section along D-D'.

The Southern block (Fig.12) represents the southern termination of the Tarboul basin. It is being separated from Central block by a major ENEWSW transfer fault (GSEU X-1). This fault is obvious in the magnetic and seismic data. This fault is obvious at the western side of the block where it represents an ENE transfer element which is dipping in the northern direction, linking two NW-SE striking Clysmic faults (RBF and RF-2 Faults).

The middle segment of this fault is being covered by quaternary deposits and are very obvious in magnetic and seismic data (Fig.13), where the GESU X-1 named as X-5 in the Strikes Seismic line (Fig.13) which is dipping in the north direction juxtaposing the Matulla formation against the Duwi-Sudr carbonates, and there is also a remarkable decrease in thickness of the PreMiocene package in the up thrown of this fault.

The Southern Block (Fig.12) is bounded from the south by Abu Shaar Fault, which is an ENE striking normal fault juxtaposing the Miocene carbonates against the quaternary deposits. The Miocene carbonates is named as Abu carbonate complex plateau. this carbonate complex is a $10 \mathrm{~km} \times 10 \mathrm{~km}$ mixed carbonate Siliclastic platform. Abu Shaar Platform dipping about 5-7 ${ }^{\circ}$ towards the SW direction. the Abu shaar carbonate complex is dissected by ENE Normal fault (Abu Shaar F-2), where it is juxtaposing the basement rocks against the Abu Shaar carbonate complex.

The Southern Block (Fig.12) is an intra Basinal horst that is bounded from the north by the major ENE transfer fault (GSEU X-1) and from the south by another ENE normal fault (GSEU X-3) which dips in the south direction and juxtaposing the Matulla and Eocene rocks against the Abu Shaar carbonate 
complex. There is also a small fault parallel to GSEU X-3, which is juxtaposing the Sudr Formation against the Eocene formation.

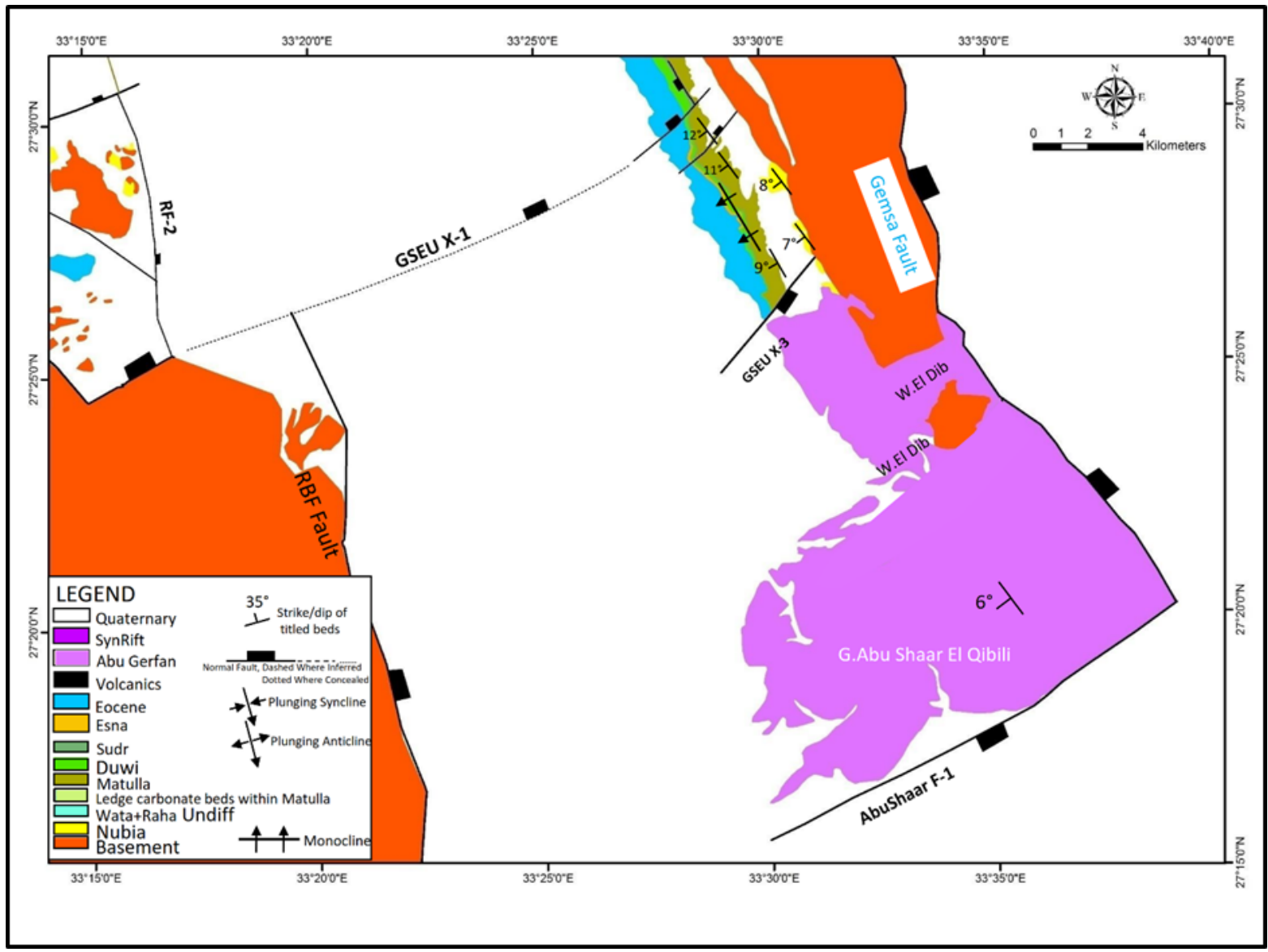

Fig.12: Surface Geological map of Gebel Sufr El Ush Block.

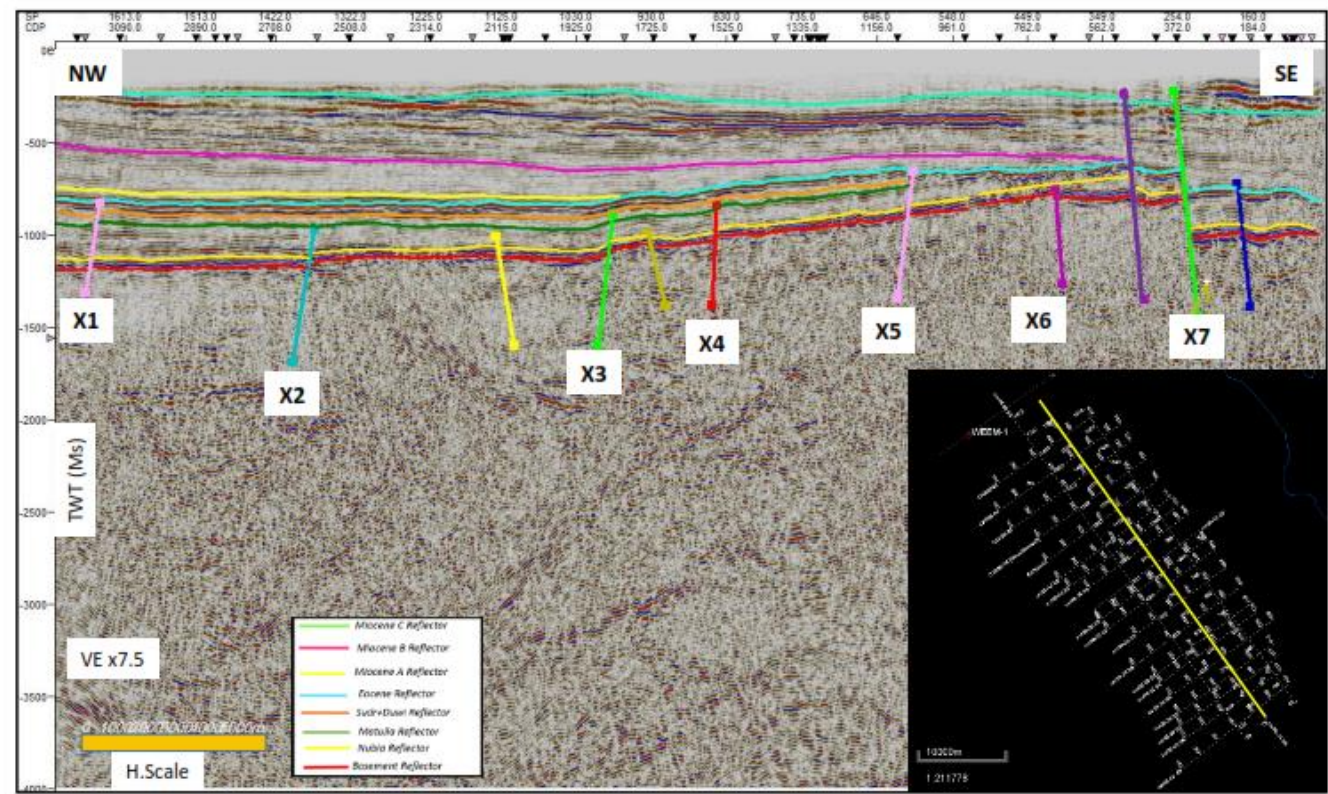

Fig.13: NW-SE Seismic Strike line (LineCXR98-03). 


\section{Magnetic Data Interpretation and Integration}

In 2008, High-resolution aeromagnetic survey covering $586 \mathrm{Sq} . \mathrm{km} 2$ of Tarboul basin was acquired in Gebel Sufr El Mellaha and Sufr El Ush blocks (Fig.14) by Archimedes Geophysical. The flight lines spacing was $250 \mathrm{~m}$ by $250 \mathrm{~m}$ directed NE and NW respectively. The purpose of this survey was to delineate depth to basement in Tarboul basin and reveal major basin structures.

The depth to basement map processed from aeromagnetic survey (Fig.15) shows a multiple structural lineaments affecting the two blocks. These lineaments (Fig.15) have $\mathrm{N} 290^{\circ}-320^{\circ} \mathrm{W}$ and $\mathrm{N} 0{ }^{\circ}-60^{\circ}$ E predominant orientations. The map shows difference in basement elevation between the central and Southern blocks. The study area is then being subdivided into two main structural domains: Domain A which represents the main trough with a basement elevation ranges from $-2201 \mathrm{~m}$ to- 1200 and the Domain B which represents the platform area which has basement elevation ranges from $1200 \mathrm{~m}$ to $-444 \mathrm{~m}$. The Abu Marwa block 1 and 2 rift flanks are also can be detected by the high magnetic anomaly in the western side.

For eastern side the magnetic map shows multiple lineaments structures (Fig.15) affecting the Central and Southern Blocks. The predominant Orientation is NW-SE. These lineaments are collinear with the two Surface MF-1 and MF-2 faults. These faults are the main faults where the monocline is being developed above.

\section{Conclusions}

The integration between the surface geology, seismic and the magnetic data is very important step to do, especially in frontier basin. This integration revealed the major basin configuration and structures affecting the Tarboul basin. The Tarboul basin has been subdivided into two main structural domains: Domain A and Domain B separated by the NE striking GSEXU X-1 transfer zone. This fault is very obvious in the NW-SE strikes seismic section and on the surface outcrop.

For the western part of the Tarboul Basin, the RBF is branched at this zone into two main faults producing two main inner blocks: Abu Marwa $1 \& 2$.

For the eastern part of the area the magnetic data, shows a high magnetic anomaly which corresponds to the flexural shoulders of the Tarboul basin. This flexural shoulder is affected by many NW-SE trending lineaments. These lineaments are collinear with the MF-1 and MF-2 surface faults. 


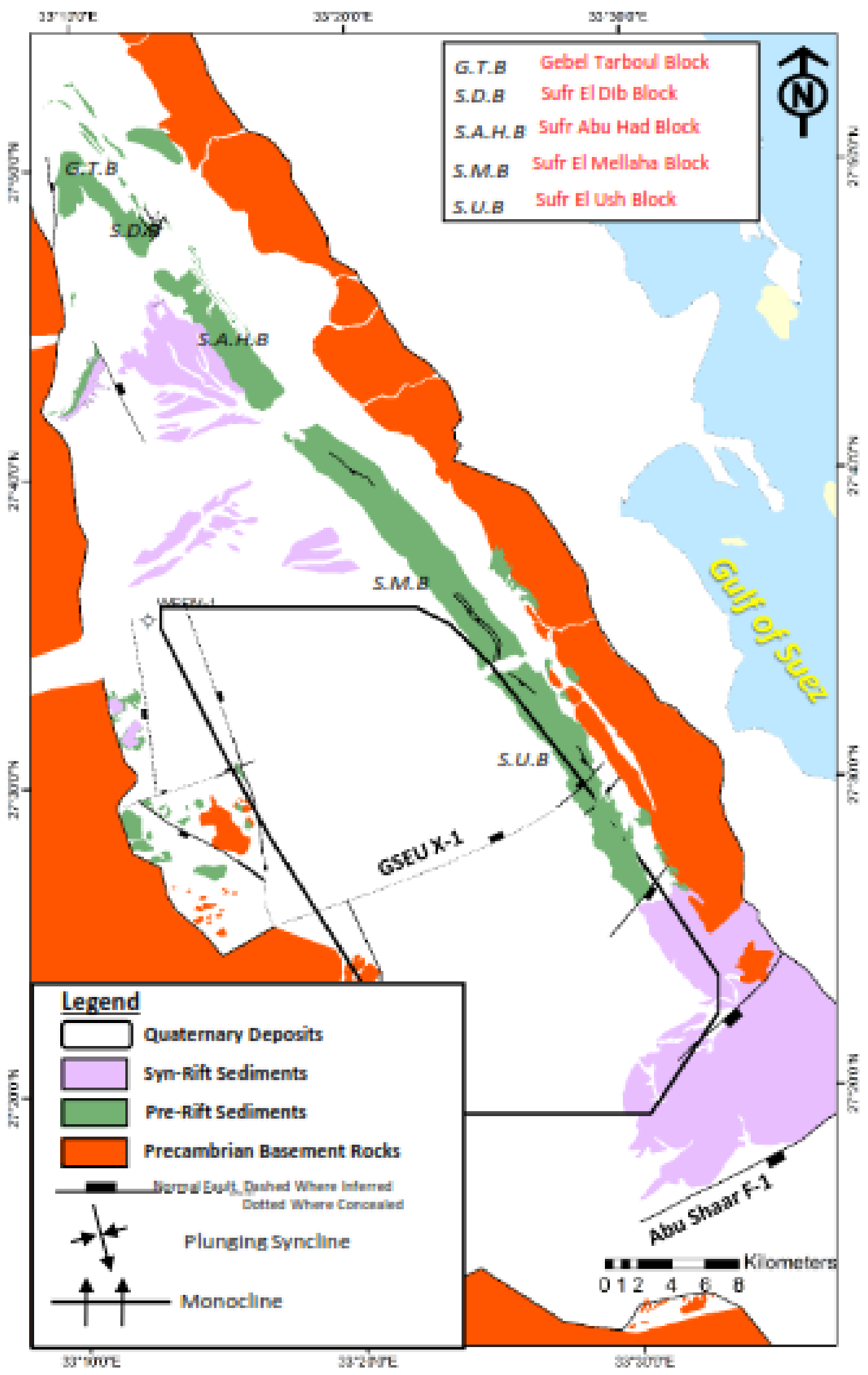

Fig.14: Geological map showing the magnetic data boundary. 


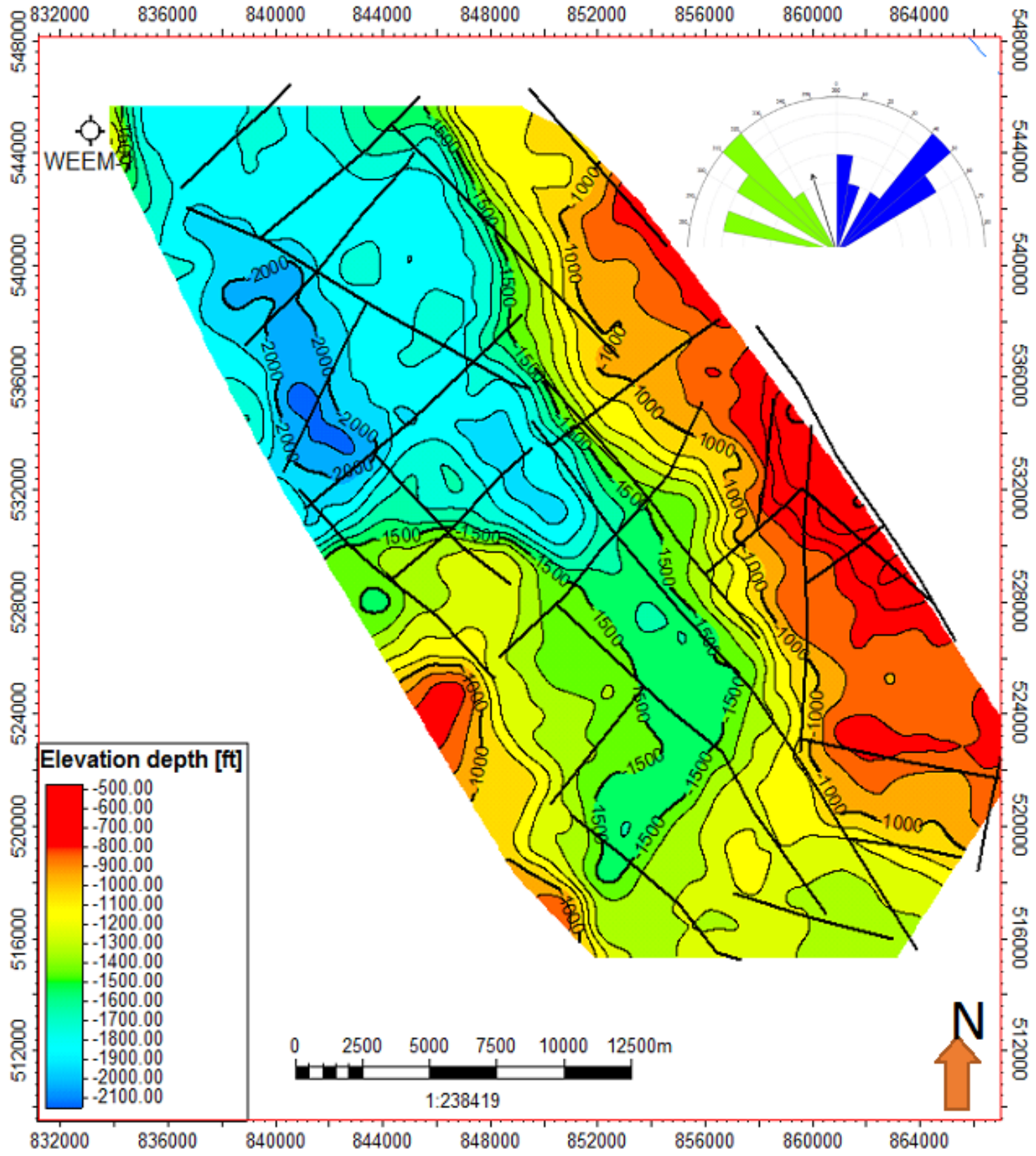

Fig.15: Depth to Basement Map (interpreted from aeromagnetic survey). 


\section{Reference}

Bosworth, W., 1985. Geometry of propagating continental rifts. Nature, 316 : 625-27.

Bosworth, W., 1995. A high-strain rift model for the southern Gulf of Suez (Egypt). In: J.J. Lambiase (Ed.), Hydrocarbon Habitat in Rift Basins, Geol. Soc. Lond. Spec. Paper 80: 75-112

Colletta, B. LE Quellec, P. Letouzy, J. and Moretti, I., 1988. Longitudinal evolution of the Suez rift structure (Egypt). Tectonophysics, 153: 221233.

Darwish, M. and EL Araby, A., 1993.Petrography and Digenetic Aspects of some Siliclastic hydrocarbon reservoirs in relation to rifting of the Gulf of Suez, Egypt. Geodynamics and sedimentation of the Red Sea-Gulf of Aden Rift System. Geol. Surv.Egypt Spec.Publ, 1: 155-187.

Darwish, M. and EL-Azabi, M., 1993.Contributions to the Miocene sequences along the western coast of the Gulf of Suez, Egypt. Egyptian J. Geology, 37: 21-47.

Garfunkel, Z., 1988. Relation between continental rifting and uplifting: evidence from the Suez rift and northern Red Sea. Tectonophysics, 150: 33-49.

Gawthrope, R.L., Sharp, I., Underhill, J.R., and Gupta, S., 1997.Linked sequence stratigraphic and structural evolution of propagating normal faults. Geology, 25: 795-798.

Mcclay, K.R., Nicols, G.J., Khalil, S.M, Darwish, M. and Bosworth, W., 1998. Extensional tectonics and sedimentation, eastern Gulf of Suez, Egypt. In: B.H. Purserand D.W.I. Bosence (Eds.), Sedimentation and Tectonics of Rift Basins: Red Sea-Gulf of Aden, Chapman and Hall, London, pp.223-238.

Mohamed Saleh Hassan, 2002: Geology and Structural Architecture of Southwest Gulf of Suez, with special emphasis on the Precambrian rocks of Gebel Zeit Area, Egypt, unpublished Thesis, Cairo University.

Mohamed Salah El Din Aboul Karamat 1987.Geology of Sedimentary Succession of Esh El Mellaha Range, Eastern Desert, Egypt, unpublished Thesis, Cairo University.

Patton, T.L., Moustafa, A.R., Nelson, R.A., and Abdine, S.A., 1994. Tectonic evolution and Structural setting of the Suez Rift. In: S.M. Landon (Ed.), Interior rift basins, Am. Ass. Petrol. Geol. Mem. 59: 755.

Said, R 1962. The Geology of Egypt.ElSevier,377pp.

Said, R 1990. The Geology of Egypt.ElSevier. 


\title{
الوضع التركيبي لحوض طريول، جنوب خليج السويس، مصر
}

\author{
اسلام شاهين 1 ، شوقي سكران² سليم صابر2
}

1 شركة أمنبكس للبترول مصر المحدودة، القاهرة، 11371، مصر 2 قسم الجيولوجيا، كلية العلوم، جامعة القاهرى، 11566، مصر

الملخص

تعتبر الجيولوجيا التركيبية السطحية ونظام البترول خطوات مهمة في دراسة وتقييم الأحواض الرسوبية. يعتبر حوض طربول من الأحواض الهامثية التي تقع في الجزء الجنوبي لخليج السويس. تمثل صخور الباليوزوي أقدم الصخور بحوض طربول بينما تمثل صخور الايوسين الأحدث. ومن الناحية التركيبية، يحد حوض طربول من الغرب فالق حد الخسف ومن الثرق فالق جمسة. يمثل الجزء الثمالي من حوض طربول انحناء منأتز بصدع حدودي حيث تتكون طية أحادية الميل. ساعد المج بين الجيولوجيا السطحية و البيانات التحت سطحية في التنبؤ بالفالق الذي أدى الى تكوين هذا التركيب. تدل صخور ما قبل الميوسين المكثوفة عند الجزء الثمالي الثرقي لحوض طربول على انخفاض رمية فالق حد الخسف وذلك نتيجة مجاورة الفالق لنطاق مرجان الانتقالي. 